\title{
波浪推算の計算領域が海上作業可否の 判定精度に及ぼす影響 \\ INFLUENCE OF CALCULATION AREA ON WAVE PREDICTION FOR MARINE WORKS IN THE PACIFIC OCEAN
}

\author{
琴浦毅 1 - 森屋陽一2・関本恒浩3 \\ Tsuyoshi KOTOURA, Yoichi MORIYA and Tsunehiro SEKIMOTO
}

\author{
1正会員 修(工） 五洋建設株式会社＼cjkstart技術研究所（二329-2746 杤木県那須塩原市四区町1534-1） \\ 2正会員 博 (工) 五洋建設株式会社 技術研究所（干329-2746 栃木県那須塩原市四区町1534-1） \\ 3フェロー 博 (工） 五洋建設株式会社 技術研究所（†329-2746 栃木県那須塩原市四区町1534-1）
}

\begin{abstract}
In marine works, it is important to get the wave prediction results for safety operation and work executable judgment. Recently, the advanced wave prediction method using the WAM model has been utilized generally in marine works. However, the accuracy of the wave prediction results is not clear in marine work conditions.

GPV wind data (GSMgl,GSMjp) from the Japan Meteorological Agency is inputted to the WAM model. The wave prediction results of some calculation areas in the Pacific Ocean are compared with the wave measurement results of NOWPHAS. The critical wave heights and periods for possible work condition are $1.0 \mathrm{~m}$ and $7.0 \mathrm{~s}$ in marine works. The influence on wave prediction of calculation area is clear for marine works in the Pacific Ocean.
\end{abstract}

Key Words : Wave prediction accuracy, WAM model, marine works, The Pacific Ocean

\section{1.はじめに}

海上作業を伴う海洋工事では，波浪条件が作業の 安全性や可否判断に大きく影響するため，波浪観測 網の整備やその活用が行われてきた ${ }^{1)}$ 。また，高度 化されつつある波浪推算モデルも作業可否判断に利 用され始めつつあり，波浪推算結果をリアルタイム に配信するシステムも構築されている22.

しかし，波浪推算モデルの推算精度に関しては， 日本近海で発生する気象擾乱に起因寸る高波浪に着 目して検討されたものが多く, 海上工事の施工可否 に着目して波高 $1 \mathrm{~m}$ 程度以下の波浪の予測精度に関し て検討された例は少ない ${ }^{3)}$ 。また，近年では現地観 測値と波浪予測值を同化することで，波浪観測が行 われていない地点に関しても，平常時も含めた予測 精度の向上を図る取り組みがなされている ${ }^{4)}$ 。しか し，観測值が久測するなどの事態を想定すると，モ デル自体の精度向上を図るべきなのも疑いようがな い事実である。

また，太平洋沿岸では遠方からのうねりが頻繁に 来襲する海象条件であるため, 可能な限り計算領域 を広げることが望まれるが，計算領域の拡大は計算 負荷の増加にもつながることなどから，予測システ ムや長期波浪データベース作成においても太平洋側
の計算領域について検討が十分になされていない ${ }^{5}$ ７)。一方，近年では計算機の性能向上や計算手法 の高度化などが著しく，これからは計算領域を拡大 した計算も実務的に可能になることが予想される.

そこで, 本研究では, 太平洋の計算領域に着目し て，6時間毎の気象庁GPV（GSM全球，GSM日本域）の 海上風データを入力としたWAMモデル8) 用いた波 浪推算を実施し，GPS波浪計，NOWPHAS（全国港湾海 洋波浪情報網）の観測結果と比較することで，波浪 の予測精度を明確にすることを目的とした。また， 常陸那珂港での実際のケーソン据付工事の作業実施 状況と波浪予測結果を比較し, 波浪予測の作業可否 判断への適用の可能性を検討した.

\section{2. 波浪予測方法の概要}

波浪推算モデルとしてはWAMモデルを用い，モデ ルの各パラメータを表-1, 解析領域を図 $-1,2$ に示 した。解析は $0.5^{\circ}$ 格子の気象庁 GPV (GSM全球) の 海上風データをWAMモデルの入力条件とし太平洋領 域を計算し，約 $20 \mathrm{~km}$ 格子の気象庁GPV（GSM日本域） 海上風データを約 $10 \mathrm{~km}$ 格子に線形補間した計算領域 (1)に接続した。ただし，今回の検討では太平洋の計 
表-1 WAMモデルのパラメータの設定

\begin{tabular}{|c|c|c|c|c|c|}
\hline 領域番号 & (1) & (2) & (3) & (4) & (5) \\
\hline 計算領域（北緯） & $\begin{array}{c}20^{\circ} \\
\sim \\
50^{\circ}\end{array}$ & \multicolumn{2}{|c|}{$\begin{array}{c}0^{\circ} \\
\sim \\
60^{\circ}\end{array}$} & $\begin{array}{c}-40^{\circ} \\
\sim \\
60^{\circ}\end{array}$ & $\begin{array}{c}-70^{\circ} \\
\sim \\
60^{\circ}\end{array}$ \\
\hline 計算領域（東経） & $\begin{array}{c}120^{\circ} \\
\sim \\
150^{\circ}\end{array}$ & $\begin{array}{c}117^{\circ} \\
\sim \\
201^{\circ}\end{array}$ & & $\begin{array}{c}117^{\circ} \\
\sim \\
295^{\circ}\end{array}$ & \\
\hline 最小周波数 & \multicolumn{5}{|c|}{$0.042 \mathrm{~Hz}$} \\
\hline 周波数分割数 & \multicolumn{5}{|c|}{35} \\
\hline 方向分割数 & \multicolumn{5}{|c|}{16} \\
\hline 水深条件 & \multicolumn{5}{|c|}{ 深海 } \\
\hline 空間間隔 & $0.1^{\circ}$ & \multicolumn{4}{|c|}{$0.5^{\circ}$} \\
\hline 伝播計算時間刻み & $300 \mathrm{~s}$ & \multicolumn{4}{|c|}{$900 \mathrm{~s}$} \\
\hline 風データ時間間隔 & \multicolumn{5}{|c|}{$3600 s$} \\
\hline
\end{tabular}

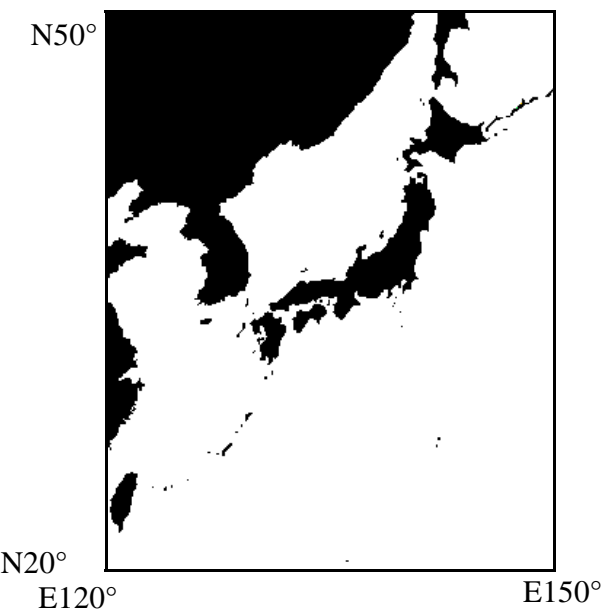

図-1＼cjkstart計算領域(1)領域図 (10km格子)

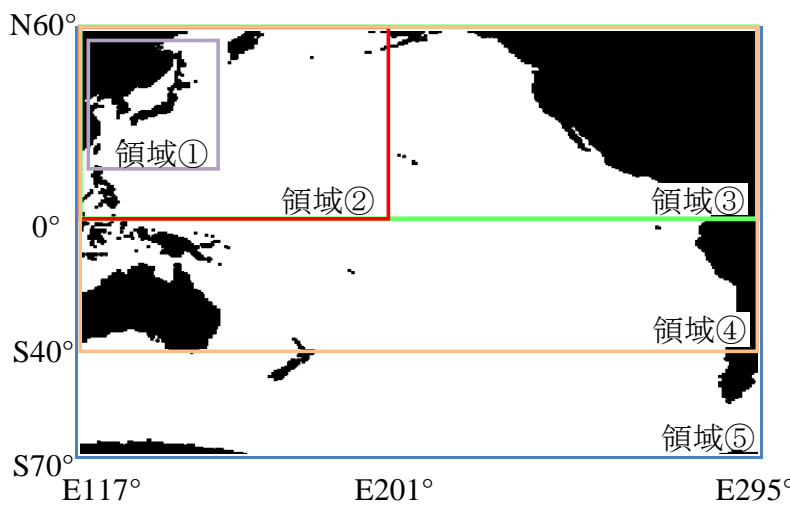

図-2 太平洋計算領域図 (0.5 格子)

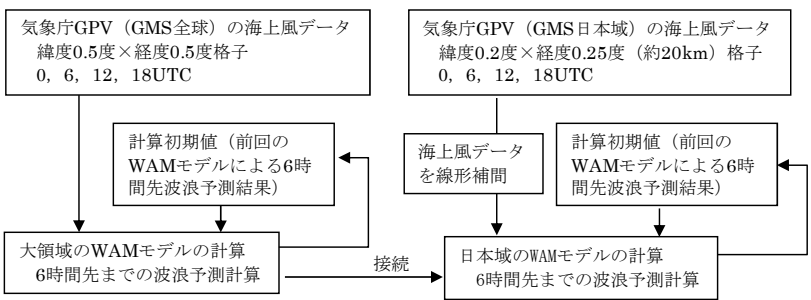

図-3 データ入力から予測までのフロー
表-2 検討対象地点とその整理番号

\begin{tabular}{|c|c|c|c|c|c|}
\hline a & 青森県東岸沖 & e & 宮城県北部沖 & $i$ & 三重県沖 \\
\hline b & 岩手県北部沖 & f & 宮城県中部沖 & $j$ & 和歌山県沖 \\
\hline c & 岩手県中部沖 & g & 福島県沖 & $k$ & 高知県西部沖 \\
\hline$d$ & 岩手県南部沖 & $h$ & 静岡県沖 & \multicolumn{2}{|c}{} \\
\hline
\end{tabular}

\begin{tabular}{|c|c|c|c|c|c|}
\hline 1 & 紋別(南) & 9 & 石巻 & 17 & 御前崎 \\
\hline 2 & 釧路 & 10 & 仙台新港 & 18 & 潮岬 \\
\hline 3 & 十勝 & 11 & 相馬 & 19 & 室津 \\
\hline 4 & 苫小牧 & 12 & 小名浜 & 20 & 高知 \\
\hline 5 & むつ小川原 & 13 & 常陸那珂 & 21 & 上川口 \\
\hline 6 & 八戸 & 14 & 波浮 & 22 & 細島 \\
\hline 7 & 久慈 & 15 & 下田 & 23 & 中城湾 \\
\hline 8 & 釜石 & 16 & 清水 & \multicolumn{2}{|c}{} \\
\hline
\end{tabular}

算領域の相違による検証を行うために，太平洋の計 算領域を 4 領域 (領域(2)〜領域(5)) 設定した。この データ入力から予測結果出力までのフローを図-3に 示した。なお，気象庁の全球波浪GPVは南緯 $75^{\circ}$ ま での範囲であるが，球面座標系においては南緯 $70^{\circ}$ 〜 $75^{\circ}$ の専有面積が小さいこと, 経度の距離が小さ くなるため時間刻みを小さくする必要があること, 領域(5)との比較から日本沿岸には有意な差は無いこ とを確認したことなどから, 最南端を領域(5)の南緯 $70^{\circ}$ とした。

予測精度の検証は，有義波高，有義波周期および 波向について，表-2に示す太平洋側のGPS波浪計 （2010年：速報值）とナウファス波高計 (2008年：確 定值)の観測値より行った.

\section{3. 外洋の予測精度}

\section{（1）領域別の時系列比較}

外洋の代表的な地点として岩手県南部沖GPS波浪 計の観測結果と予測結果の領域毎の比較を図-4に示 している。

領域(1)を計算領域とした場合，日本海側では良好 な予測精度を有することを確認しているが3)，岩手 県南部沖では有義波高, 有義波周期とも観測值より 過小評価している。これは，日本海側の波浪は，こ の領域内で発生する気象擾乱に起因するため波浪が 支配的であるのに対し，太平洋側ではこの領域外か ら伝播する波が存在するためと考えられる。

領域(2は北西太平洋に拡大した領域であり，領域 (1) と比較すると波高，周期ともに精度が向上してお り，波高のみを対象とするのであればこの領域で十 分であるといえる. しかし，夏期の周期を見ると周 期を過小評価していることから，この領域のさらに 外からの波の伝播があることを示唆している.

領域(3は北東太平洋領域に拡大した領域であるが, 領域(2)と比較して有意な差は認められない。このこ とから, 北東太平洋領域がわが国の太平洋側の波浪 に及ぼす影響は小さいと考えられる。

領域(4は南半球まで拡大した領域であり，この領 


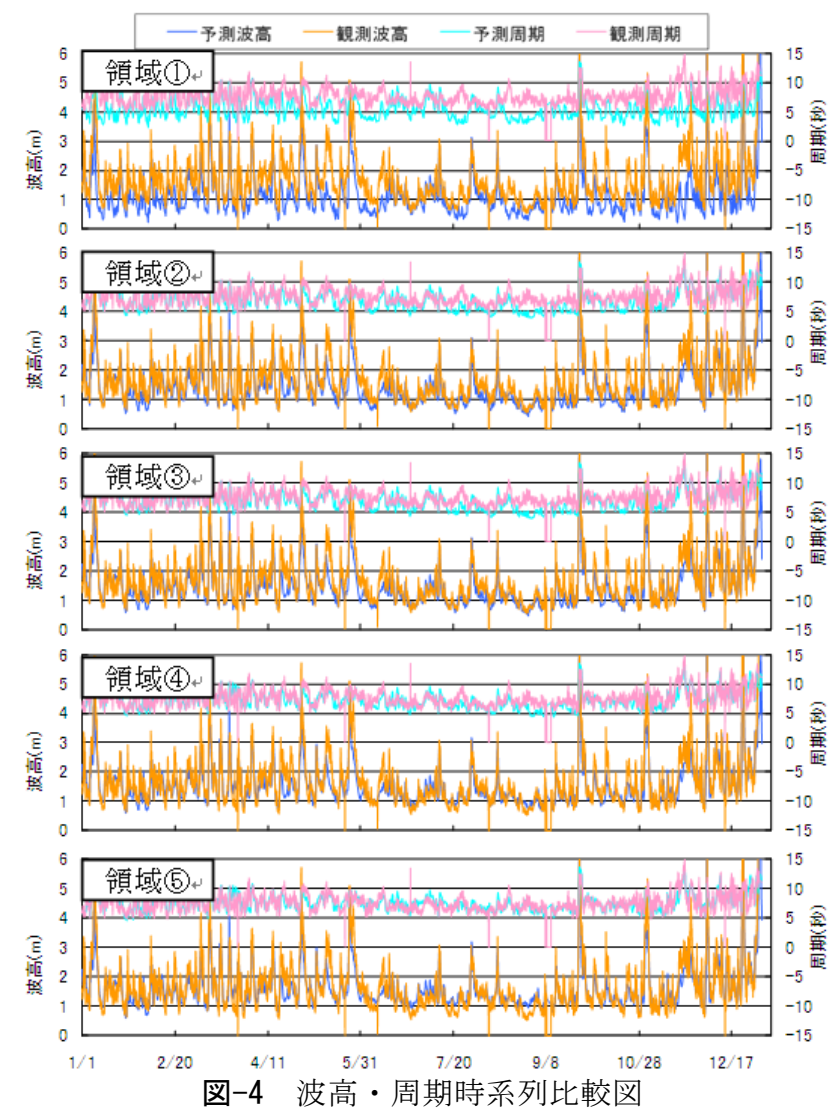

(GPS波浪計：岩手県南部沖 (2010年))
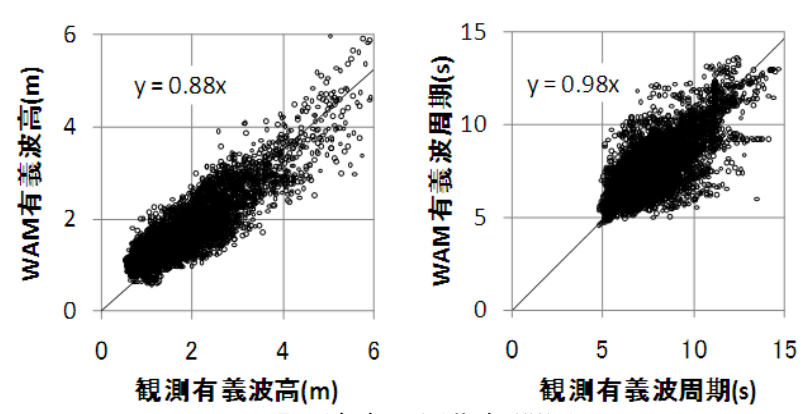

図 -5 波高 $\cdot$ 周期相関図

(領域(5), 岩手県南部沖)

域では夏期の周期予測精度の改善がみられる。また， 南半球の南緯 $40^{\circ} \sim 70^{\circ}$ の暴風域を含む領域(5)では 周期については観測值と予測值がほぼ一致する結果 が得られているものの，波高においては夏期に過大 評価する傾向が認められる。これは，うねりの伝播 計算に課題があることを示唆している.

\section{（2）領域別の相関比較}

図-5に岩手県南部沖の有義波高, 有義波周期の観 測值と予測值の相関図を示した。観測值と予測值が 一致すればその勾配 (回帰係数) は1となるが，有義 波高の回帰係数は0.87, 有義波周期の回帰係数は 0.98である。また，図-6，7に表-2のGPS波浪計の有 義波高, 有義波周期の回帰係数について領域毎に整 理した。この図で領域(1)は全体的に0.8以下と過小 評価であり，計算領域が広くなるにつれて回帰係数

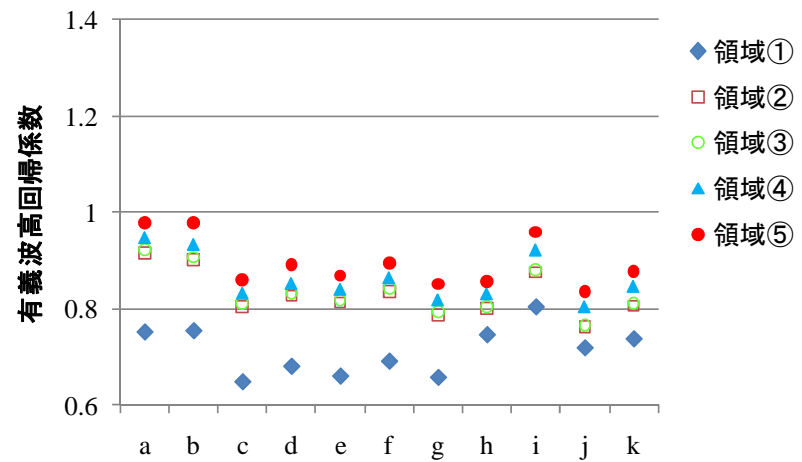

図-6 有義波高回帰係数

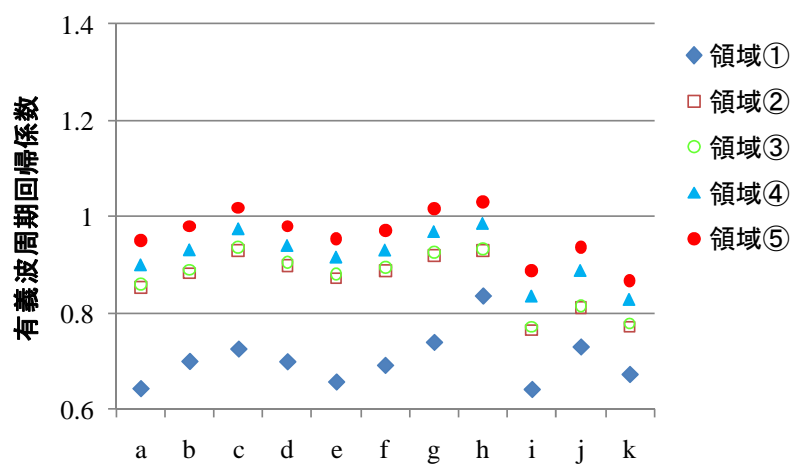

図-7 有義波周期回帰係数

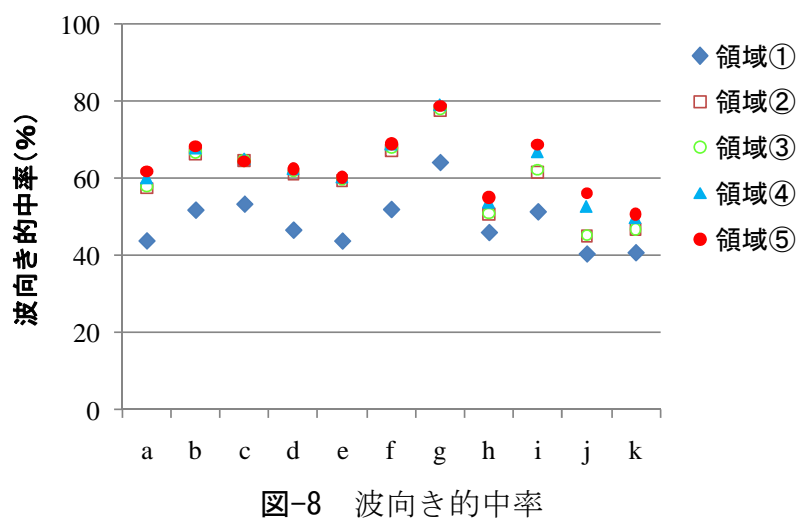

が1.0に近づいている。また，領域(2), (3)では顕著 な相違が無く，このことからも北東太平洋の影響は 小さいと判断できる. 領域(4)，(5)では特に周期で西 日本の精度向上が顕著であることから，周期に関し て領域(2), (3)の南側領域の不足を示唆している.

また，図-8は観測值を基準に予測值が波向士22.5 度の範囲内であれば的中として算定した波向き的中 率である。この図において領域(2)〜 (5)で的中率が向 上しているが, 領域(4), (5)では西日本で精度が一層 向上していることから, 西日本の波向きには南半球 からのらねりが影響すると考えられる。

\section{4. 沿岸域の予測精度}

（1）領域別の時系列比較

沿岸域の代表的な地点として常陸那珂 (水深 $30.3 \mathrm{~m})$ の観測結果と予測結果の領域毎の比較を図-9 

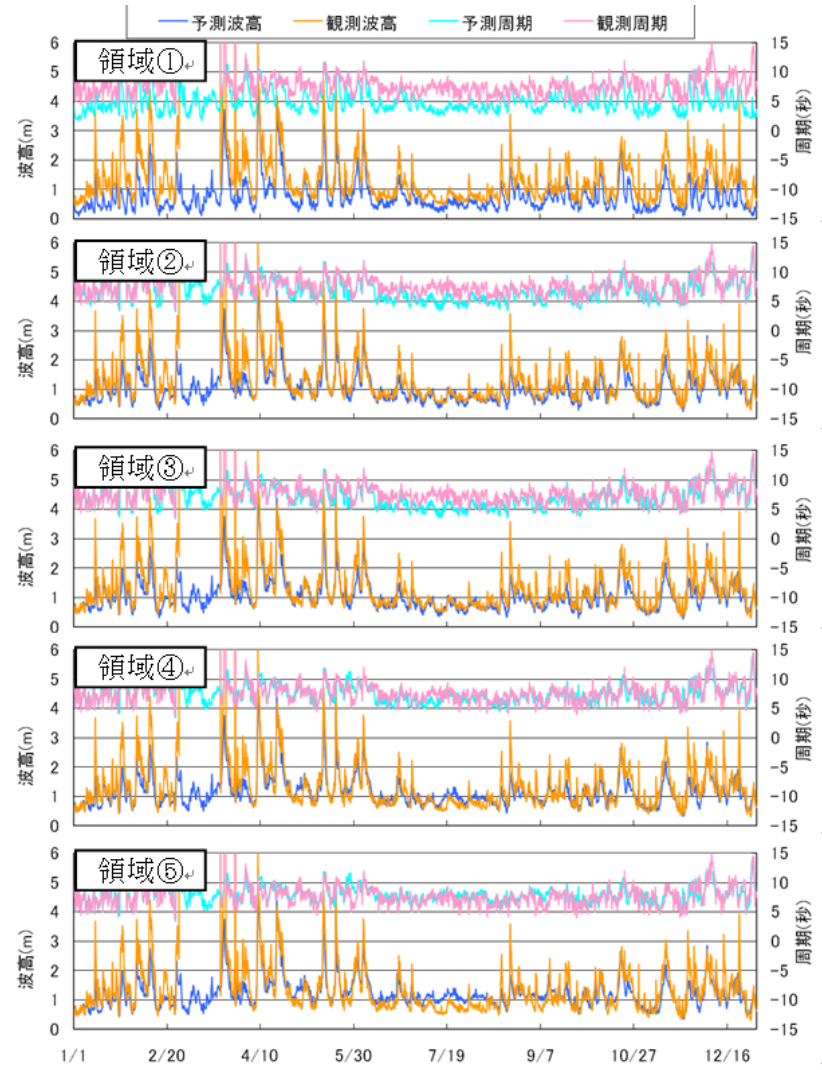

図-9 波高 - 周期時系列比較図 (ナウファス常陸那珂(2008年))
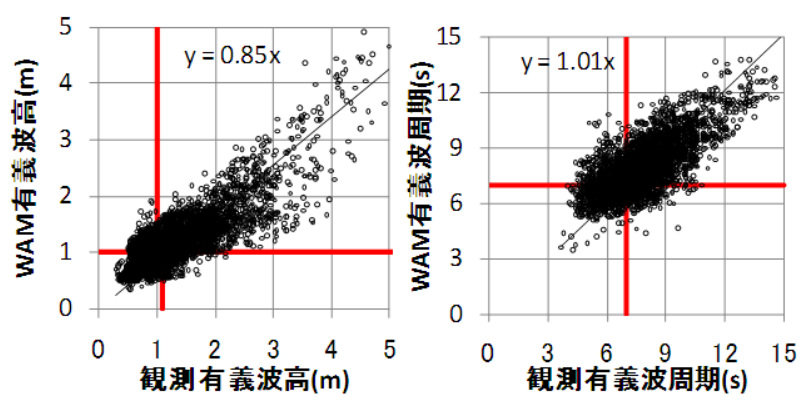

図-10 波高・周期相関図(領域(5)，常陸那珂）

に示している.

領域(1)有義波高，有義波周期ともに観測值より 過小評価しているのは岩手県南部沖GPS波浪計と同 様であり，計算領域が不十分であると考えられる.

領域(2)，(3)では領域(1) と比較すると有義波高が改 善し，良好な一致がみられる。また，有義波周期も 精度の改善がみられるものの，夏期の低波浪時期の 周期が過小評価となっており，この地点でも南側の 計算領域の不足が示唆される.

領域(4)，(5)では夏期の有義波高が多少過大評価す る傾向があるものの，周期に関しては観測值と良く 対応している.

\section{（2）領域別の相関比較}

図-10は常陸那珂の有義波高，有義波周期の観測 值と予測值の相関図であり, 有義波高の回帰係数は 0.85 , 有義波周期の回帰係数は 1.01 と良く対応して いる.また，図-11，12は表-2のナウファス地点の

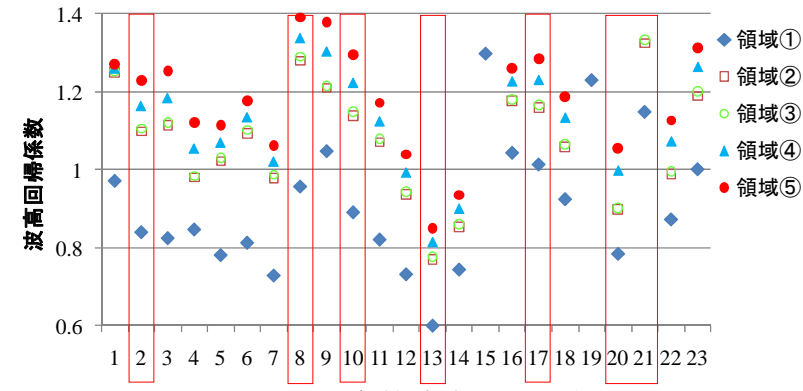

図-11 有義波高回帰係数

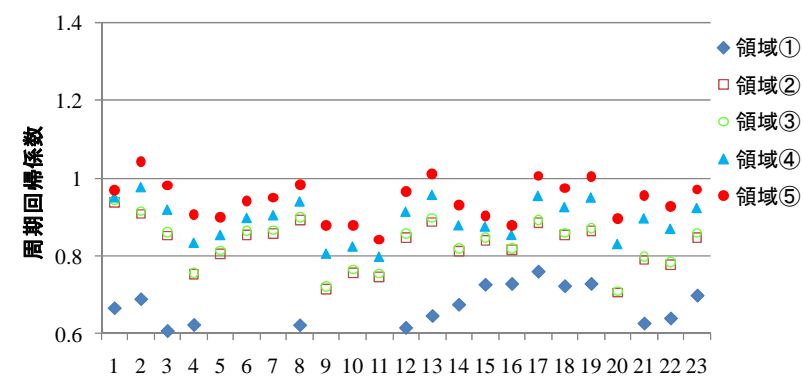

図-12 有義波周期回帰係数

有義波高, 有義波周期の回帰係数である. 有義波高 の回帰係数は領域の拡大につれて増加しているが, その值は地点によって1.0から大きく外れている. その一方で有義波周期の回帰係数は領域の桩大につ れて増加し，1.0に近づいている.

GPS波浪計では，領域の桩大に伴い有義波高と有 義波周期の回帰係数が1.0に近づき，精度が向上し たものの, 沿岸部では回帰係数の傾向は異なる. 特 に有義波高の回帰係数は釜石 (No. 8)，上川口 (No.21)などで大きい。これは計算格子サイズ(約 $10 \mathrm{~km}$ 格子)がリアス式海岸などの複雑な地形につい ての再現性が不十分であることを示唆している.

また，これと同時に海底地形の影響が考えられる。 日本海側では周期が短く，水深波長比が大きいため, 海底地形の影響が小さいナウファス地点が多い。 そ れに対し，たとえば，常陸那珂で観測される平均的 な有義波周期は 8 秒程度, 沖波波長は $L_{0}=99.84 \mathrm{~m}$ とな り，波高計水深 $(30.3 \mathrm{~m})$ との水深波長比は 0.30 とな ることから観測值には海底地形の影響が含まれると 考えられる。今回の予測計算では深海モデルのWAM を用いているため，海底の影響を受けない結果が算 出されため, 有義波高の回帰係数に差異が出たと考 えられる。

\section{（3）作業可否基準と誤差許容値}

予測の的中率は作業可否の基準波高を $1.0 \mathrm{~m}, 7.0 \mathrm{~s}$ とした場合，図-13に示すように，予測波高 $1.0 \mathrm{~m}$ 以 下かつ観測波高 $1.1 \mathrm{~m}$ 以下は稼働的中，予測波高 $1.0 \mathrm{~m}$ より大きくかつ観測波高 $1.0 \mathrm{~m}$ よりきい場合は不稼 働的中となる. また, 周期については予測周期 $7.0 \mathrm{~s}$ 以下かつ観測周期 $7.0 \mathrm{~s}$ 以下は稼働的中，予測周期 7. 0 sより大きくかつ観測周期 7.0 sより大きい場合は 不稼働的中となる. 

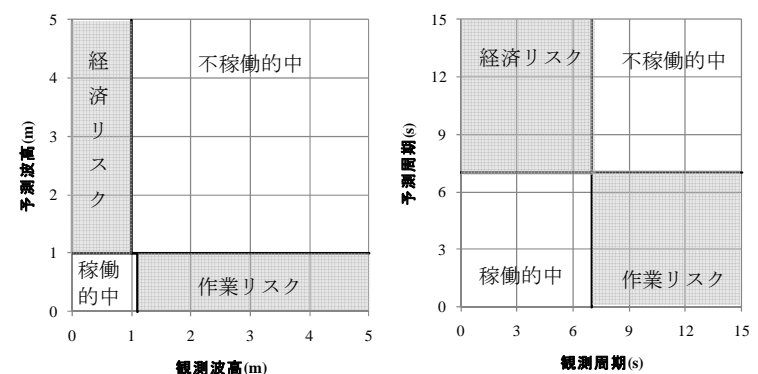

図-13 的中率の定義（波高許容誤差 $+10 \mathrm{~cm}$ ）

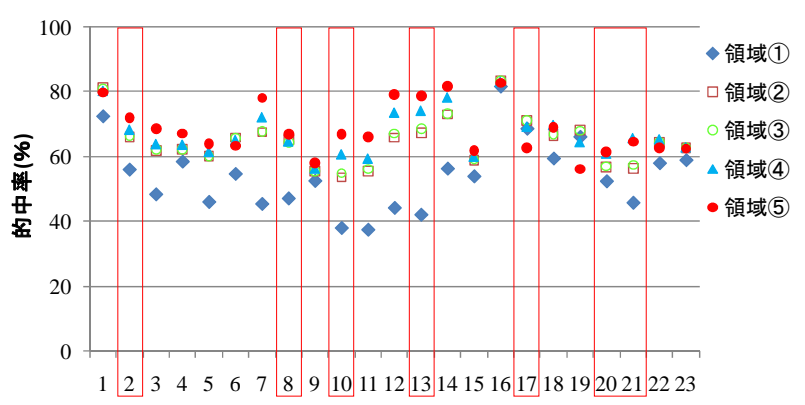

図-14 ナウファス地点の的中率
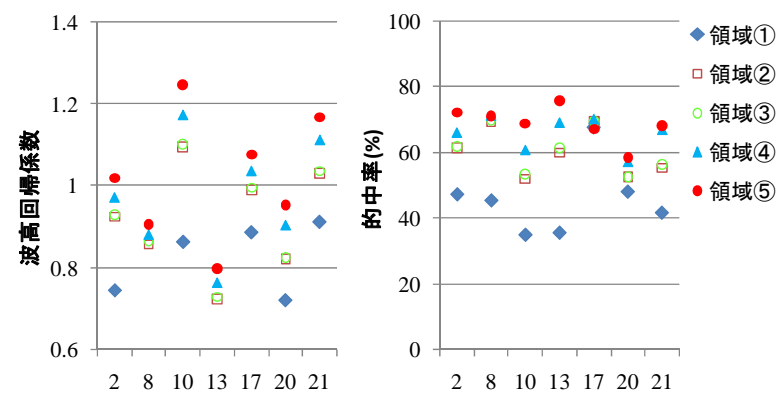

図-15 浅海域を考慮した波高回帰係数，的中率

また，予測值が基準值より大きく，観測值が基準值 未満の場合は，作業ができる条件であるのに作業を 中止することになるため，経済リスクとなり，逆に， 予測值が基準值以下で観測值が基準值より大きい場 合は，作業を行うという判断をしたのに，実際の波 高は作業限界を超えているので，作業リスクとなる

なお，データの整理は 1 時間毎に観測值と計算值 を比較し, 波高, 周期のいずれもが基準值以下で あった時を稼働可，いずれかが基準值を上回った場 合を不稼働とし, 的中率は全データに対する的中 データの比率で定義される.

\section{（4）稼働不稼働的中率}

図-14に表-2のナウファス地点における稼働不稼 働の的中率について整理した. 前述したように計算 には計算格子を下回る地形や海底地形の影響が波高 に考慮されていない。 そのため, 波高に関しては経 済リスクが増加して的中率が低下寸る。 また, 領域 が狭いと周期を過小評価するため, 周期作業リスク が増加して的中率が低下寸る。これらが総合的に影 響した結果として，全体的には領域が広い方が的中 率は高い。なお，西日本側は来襲する波浪周期が若 干短く, 周期NGの事例が少ないことが，領域(2)～(5)

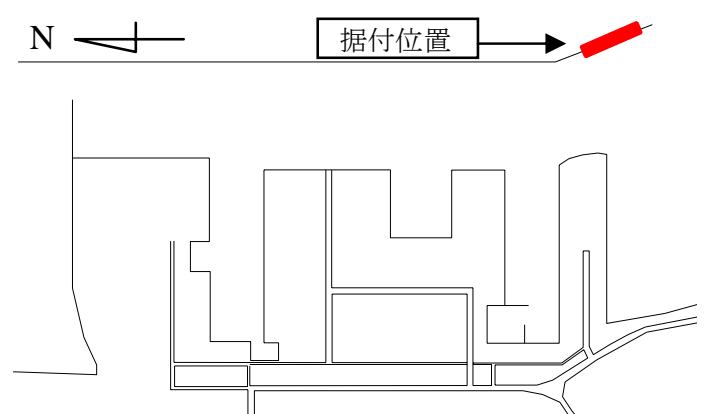

図-16 常陸那珂港の平面図とケーソン据付位置

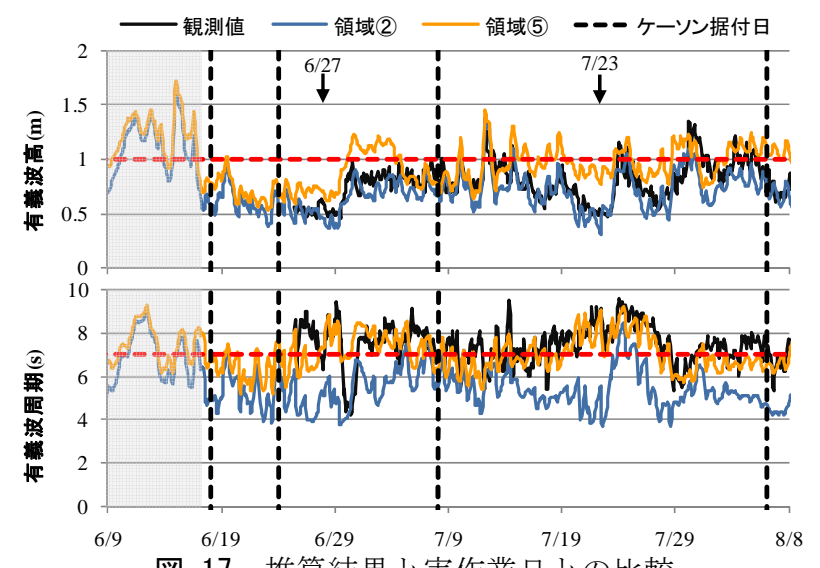

図-17 推算結果と実作業日との比較

に大きな差が出ない理由と考えられる.

\section{（5）浅海域の波浪変形の影響}

図-11，14において赤枠で囲った地点周辺の浅海 域についてエネルギー平衡方程式を用いた波浪変形 計算を行い, WAMの計算格子 $\left(0.1^{\circ}\right.$ 格子 $)$ 以下の地形 の遮蔽や海底地形の効果を考慮した波高回帰係数, 的中率を図-15に整理した。

波高回帰係数はほとんどの地点で 1 に近づき, 図一 11と比較すると精度が向上しており，これらの地点 では浅海域の波浪変形の評価が不可欠であるといえ る. その一方で, 的中率においては顕著な精度向上 が確認できない。 これは, 太平洋側においては周期 $\mathrm{NG}$ の港湾が多く, 波高の精度の向上が的中率に影響 しなかったためである。

\section{5. 波浪予測の実務への適用}

\section{（1）常陸那珂港ケーソン据付工事の概要}

太平洋側の常陸那珂港のケーソン据付工事を例に, 波高 $1.0 \mathrm{~m}$, 周期 7.0 秒を作業可否の基準として, 実 際にケーソンを据え付けた日の海象条件と波浪予測 結果との比較を行った. 常陸那珂港の平面図とケー ソン据付位置を図-16に示す.

検討対象期間はケーソン据付工事が行われていた 2010 年 6 月 9 日から 2010 年 8 月 8 日までの約 2 カ 月間とした。 


\section{（2）予測結果とケーソン据付期間の比較}

図-17は領域(2)，(5)の有義波高と有義波周期につ いて, 浅海域の波浪変形を考慮した予測值, 観測值 の比較であり, 実際のケーソン据付日 (合計 4 日) も あわせて示している.

観測值において，有義波高は1.0mを下回る日が多 いのに対し, 有義波周期は7.0 秒を上回る日が多く, 作業可否は周期基準值が支配的である.

領域(2)有義波高については観測值との対応は良 いのに対し，有義波周期は高波浪時期を除いては5 秒前後と過小評価しており, 周期稼働可条件が多く なっている．ケーソン据付日は稼働可条件となり， 的中しているといえるが，6月27日，7月23日では， 観測值においては周期NGとなるのに対し, 予測結果 では作業可となり作業リスクとなっている.

領域(5)では高波浪期間の有義波高, 有義波周期の 予測精度は高いものの, 周期が 7.0 秒を超える低波 浪期間において有義波高を過大評価寸る傾向がみら れ，波高稼働不可条件が観測值より多くなっている。 その一方で, 有義波周期については観測值と良く対 応しており, 周期稼働条件はほぼ対応している。ま た，ケーソン据付日で稼働可条件となり，6月27日， 7月 23 日で周期NGとなるなど観測值と対応している.

\section{（3）計算領域の設定}

これまでの検討から, 波高值のみで稼働可否判定 を行う場合は領域(2)で良いと考えられるが，周期を 含めて作業可否を評価する場合は作業リスクが増大 する可能性がある. したがって, 周期を含めた稼働 可否判定をする場合は領域(5)が領域(2)より適切であ ると判断できる.

領域(2において領域外をソースとするうねりを入 力できれば周期精度の向上が期待できるが，領域外 の気象擾乱によるうねりを評価するのは困難であり, 計算領域を広げる方が実務的であろう。領域(5)夏 期低波浪期間に波高を過大評価寸る傾向は，GPS波 浪計においても確認されている。この要因は明確で はないが，南半球からのうねりが影響していること は明らかであり, 非線形相互作用や数值分散などを 検討し, 波浪モデルの更なる高度化が必要である ${ }^{9)}$.

\section{5. おわりに}

本研究により, 得られた結論をまとめると以下と なる.

(1) 気象庁 GPV（GSM 全球, 日本域）の海上風デー 夕を入力とした WAM モデルによる太平洋側の外洋の 波浪予測精度は，計算領域を南半球まで広げること で, 波高, 周期, 波向きの精度向上が期待できる.

(2) 浅海域で地形の遮蔽と海底地形の影響を受ける ような予測出力点の場合には, 予測精度の及ぼす格 子サイズと海底地形による波の変形の影響は大きく，
浅海域の波浪変形を評価することが期待される.

(3) 常陸那珂港のケーソン据付工事を例に, 波浪予 測結果と据付日を比較したところ, 稼働可条件と対 応した. また, 波高值のみで稼働可否判定を行う場 合は領域(2)で良いが，周期を含めた稼働可否判定を する場合は領域(5)が領域(2)より適切である.

以上より，うねりの計算精度に課題はあるものの， 太平洋沿岸において, 海上作業の稼働を周期も含め て検討する場合, 南半球の南緯 $40^{\circ} \sim 70^{\circ}$ の暴風 域を含んだ領域で検討することが望まれる.

謝辞 : 本研究を行うにあたり, 九州大学大学院の橋 本典明教授には，WAMモデルを用いた波浪予測につ いて有益な助言をいただきました。五洋株式会社常 陸那珂工事事務所の樋口慎一郎所長には, 常陸那珂 港のケーソン据付工事で施工の情報を提供していた だきました。また，波浪予測結果の検証に利用した GPS波浪計, NOWPHASデータは港湾技術研究所海象情 報研究室のHPより入手させていただきました。ここ に記して関係者に謝意を表します。

\section{参考文献}

1) 河合弘泰・佐藤真・川口浩二：全国港湾海洋波浪観測 年報 (NOWPHAS2008)，港空研資料，No1209，93p，2010.

2) 辰巳賢一, 安田誠宏, 森信人, 間瀬肇: リアルタイム 気象・水象予測の Web 配信システムの開発, 海洋開発 論文集，第 25 巻, pp. 891-896, 2009.

3) 森屋陽一・琴浦毅・関本恒浩: 日本海における波浪推 算モデルを用いた海上・潜水作業可否の予測精度, 海 洋開発論文集，第 26 巻, pp. 447-452, 2010.

4) 水口幸司 - 大下善幸 - 室善一朗 - 高山知司 ・ 岡田弘 三・宇都宮好博：「うねり性波浪」予測・監視モデル の可能性と的確性について, 土木学会論文集B2（海岸 工学) Vol. 66, No. 1, pp. 146-150, 2010

5) 小林智尚, 佐々木博一, 吉野純, 安田孝志: ERA40に もとづく日本列島周辺長期波浪データベースの構築 : 海岸工学論文集, 第 54 巻, pp. 141-145. 2007

6) 橋本 典明, 鈴山勝之, 永井紀彦: ECMWF 風 (Operational data, ERA15, ERA40) による長期波浪 推算精度の検討, 海岸工学論文集, 第 51 巻, pp. 201205, 2004

7)山口正隆, 大福学, 畑田佳男, 野中浩一, 平塚 敬樹：わが国周辺海域および沿岸における 2 種類の長 期波浪資料の精度の比較, 海岸工学論文集, 第 51 巻, pp. 166-170, 2004

8) 橋本典明, 川口浩二, 真期俊行, 永井紀彦: 第 3 世代 波浪推算法（WAM）の推算精度に関寸る検討, 港湾技 術研究所報告, 第 38 巻, 第 4 号, 1999.

9) 橋本典明, 川口浩二, 鈴山勝之, 山城 賢, 児玉充 由: 非線形相互作用の高精度化が波浪推算に及ぼす影 響, 土木学会論文集 B2 (海岸工学) Vol. 65, No. 1, pp. 171-175, 2009 